\title{
Investment Processes and Economic Model Transformation in the Russian Federation
}

\author{
Irina Vyakina ${ }^{1}$ \\ ${ }^{1}$ Department of Economics and Production Management, Tver State Technical University, Tver, the Russian \\ Federation \\ Correspondence: Irina Vyakina, Department of Economics and Production Management, Tver State Technical \\ University, Tver, the Russian Federation. Tel: 7-910-646-2255. E-mail: ivyakina@yahoo.com
}

Received: November 13, 2016

doi:10.5539/ass.v13n1p130

\author{
Accepted: November 23, 2016 Online Published: December 20, 2016 \\ URL: http://dx.doi.org/10.5539/ass.v13n1p130
}

\begin{abstract}
The economic development is ensured by the capability of a socioeconomic system to have a stable and extended reproduction connected with investment security and its effective use. An investment scale and efficiency influence the replacement and extended reproduction of fixed capital and the society's social development. The paper aims at analyzing the specifics of economic development of Russia in the historical context based on investment criteria during the transition to regulated market; identifying the key drivers of economic growth at different stages. The phases of the Russian economy's market transformation in the course of its restructuring are systematized, the economic development peculiarities are qualitatively characterized in each phase. The common regular connections between an investment process character and an economic development level are found, key economic growth factors are identified in each phase, and their characteristics are defined. The level of a social development in the course of the Russian Federation economy's market transition is assessed.
\end{abstract}

Keywords: investment process, economic growth, social and economic development, market transition

\section{Introduction}

Development is a process of directed and natural changes of a social and economic system which results in its new and better state, improved efficiency of resource use and life quality in accordance with the needs of the society.

The reproduction character of an economic development is ensured through its investment component so the level of Russia's economic development is evaluated to a great deal in terms of investment criteria. Technical and technological development is known to be based on investment activity. Karl Marx substantiated that 'The additional capitals formed in the normal course of accumulation serve particularly as vehicles for the exploitation of new inventions and discoveries, and industrial improvements in general' (Marx, 1960, V. 23, p. 642).

Due to the lower purchasing power, drop of incomes in real terms, and the lack of borrowed funds the business activity is slowing down, a business class is refusing long-term projects connected with investments in fixed assets and mainly investing quick and highly liquid assets. The government makes investments within severe budgetary constraints caused by a plunge in prices for crude oil and a decrease of the current tax base with the decline in real household incomes and industrial and commercial business profits. The volume of foreign investments into the Russia's economy has considerably dropped, with the restricted access to international financial markets having an adverse effect on the investment market.

In addition to the complications of the global geopolitical situation, weaker foreign trade and investment technological capacity in the global economy, the destabilizing factors of the economic development are believed by Sergey Naryshkin, the Chairman of the State Duma, (Naryshkin, 2010), to be historical particularities of the economy transformation protracting for more than 20 years, adverse economic and social effects of the disintegration processes in the former Soviet Union countries, major reforms of the country's national-state structure.

The economic slowdown of Russia, after the active phase of the recovery from the crisis in 2011 from $4.29 \%$ to $3.44 \%$ in 2012 , to $1.29 \%$ in 2013 , to $0.63 \%$ (Note 1 ) in 2014 , and the planned recession in 2015 , is taking place in times of difficult geopolitical situation and dramatic drop of crude oil prices. 
Fuel and energy commodities (raw materials, in general) make up about $65 \%$ of Russia's export, about $40 \%$ of earnings derived from exports making earnings of oil and crude oil sale (Note 2). Under such circumstances the fall in oil prices results, first of all, in falling federal budget revenues considerably and necessitates the development of an austerity program, the reduction of budgetary expenses, and the search for new development prospects of the Russian economy.

Other destabilizing factors increasing the growth of the federal budget deficit and conditioning the periodical sequestering of budgets at all levels involve the incorporation of new territories requiring great investments in the development of transport and energy infrastructure and additional on-budget expenditures.

\section{Method}

The research is based on traditional methods of a scientific analysis, economic and mathematical statistics, empiric study and logic analysis, graphics simulation and econometric modeling, etc.

To assess the peculiarities of investment participation in the process of market transformation the features of the Russian economic development through its investment criteria will be considered in a particular historical context of the economic transformation and transition to the regulated market.

In 1990s Russia initiated a rapid step-by-step transition to a market economy which was considered to be of a catch-up process in relation to already developed market economies. During 90s the concentration of financial resources in the hands of owners took place. The majority of privatized enterprise owners 'squeezed' the maximum return from obsolete and worn out processing lines without concern for the equipment and technology upgrade. That led to the gradual degradation of the infrastructure, material and technical base which lay the foundation for the creation of public goods and development.

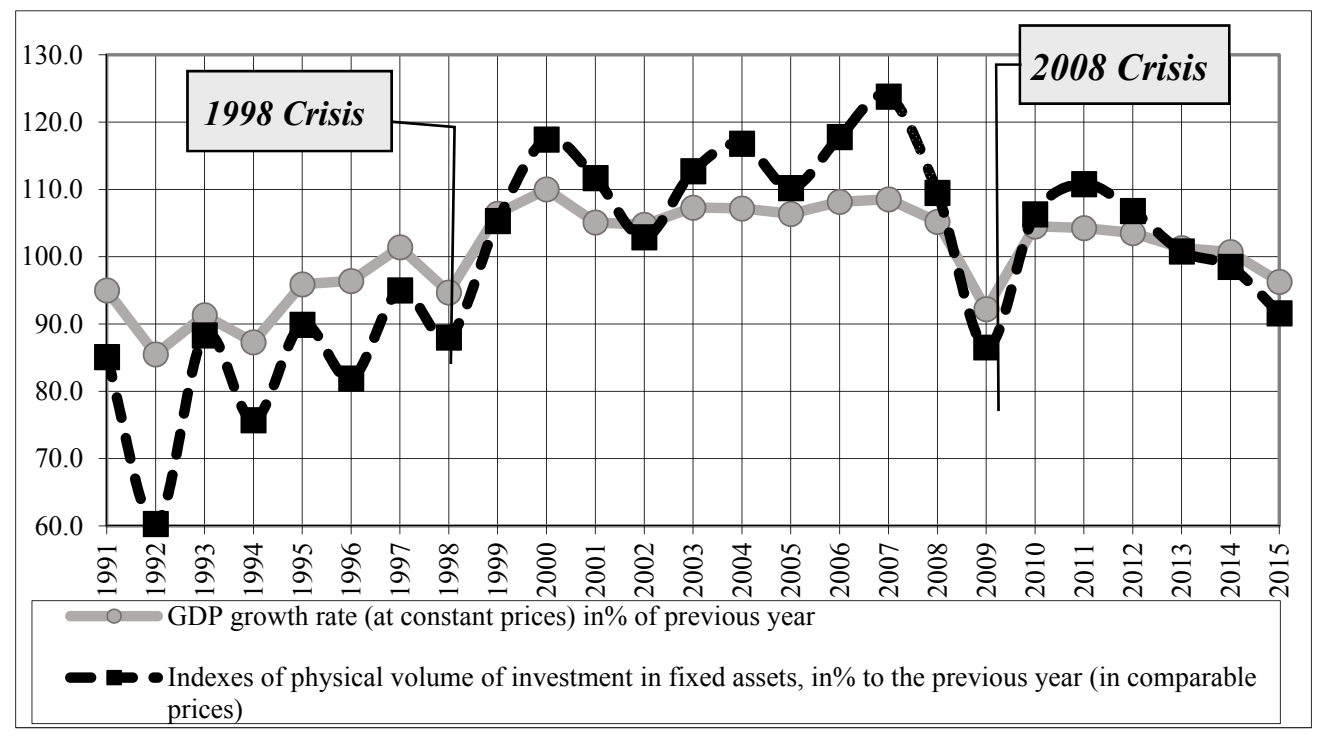

Figure 1. The dynamics of GDP growth rate and volume index of fixed capital investments within the period of market transformation in Russia (calculated by the author according to Federal State Statistics Service)

As a result, the rate of main production assets depreciation has increased considerably since 1970s (Table 1). If it did not exceed $26 \%$ in 1970, by 2014 the rate had grown by almost two-fold and reached $50 \%$.

Table 1. Fixed Capital Depreciation Level (at the end of year in \%) (Source: Federal State Statistics Service)

\begin{tabular}{cccccccccccc}
\hline Years & $\mathbf{1 9 7 0}$ & $\mathbf{1 9 8 0}$ & $\mathbf{1 9 9 0}$ & $\mathbf{1 9 9 5}$ & $\mathbf{2 0 0 0}$ & $\mathbf{2 0 0 5}$ & $\mathbf{2 0 1 0}$ & $\mathbf{2 0 1 1}$ & $\mathbf{2 0 1 2}$ & $\mathbf{2 0 1 3}$ & $\mathbf{2 0 1 4}$ \\
\hline All fixed assets & 25.7 & 36.2 & 35.6 & 39.5 & 39.3 & 45.2 & 47.1 & 47.9 & 47.7 & 48.2 & 49.0 \\
\hline
\end{tabular}

Table 2 also shows the low renewal and retirement indicators of fixed assets. The renewal coefficient throughout the economy dropped from $10.6 \%$ in 1970 s to $4.3 \%$ in 2014. At such renewal rate fixed assets must work more than 20 years until their replacement. 
Table 2. Renewal and Retirement Indicators of Fixed Assets (at the end of year in \%) (Source: Federal State Statistics Service)

\begin{tabular}{lccccccccccc}
\hline \multicolumn{1}{c}{ Years } & $\mathbf{1 9 7 0}$ & $\mathbf{1 9 8 0}$ & $\mathbf{1 9 9 0}$ & $\mathbf{1 9 9 5}$ & $\mathbf{2 0 0 0}$ & $\mathbf{2 0 0 5}$ & $\mathbf{2 0 1 0}$ & $\mathbf{2 0 1 1}$ & $\mathbf{2 0 1 2}$ & $\mathbf{2 0 1 3}$ & $\mathbf{2 0 1 4}$ \\
\hline Renewal coefficient & 10.6 & 8.1 & 6.3 & 1.9 & 1.8 & 3.0 & 3.7 & 4.6 & 4.8 & 4.6 & 4.3 \\
\hline Retirement rate & & & 2.4 & 1.9 & 1.3 & 1.1 & 0.8 & 0.8 & 0.7 & 0.7 & 0.7 \\
\hline
\end{tabular}

To assess the investment influence on Russia's economy transformation in transition to a regulated market the process of market reforms is logically assumed to be divided into three periods with 1998 and 2008 crises as boundary points (Figure 1 shows the dynamics of GDP growth rate and volume index of fixed capital investments within the period of market transformation in Russia).

Each period between the two crises shows rather sustainable trends influencing the key characteristics of the country's economic growth correlating explicitly with crude oil prices on the global market (Fig. 2).

Figure 2 illustrates the market transition phases of the Russian economy.

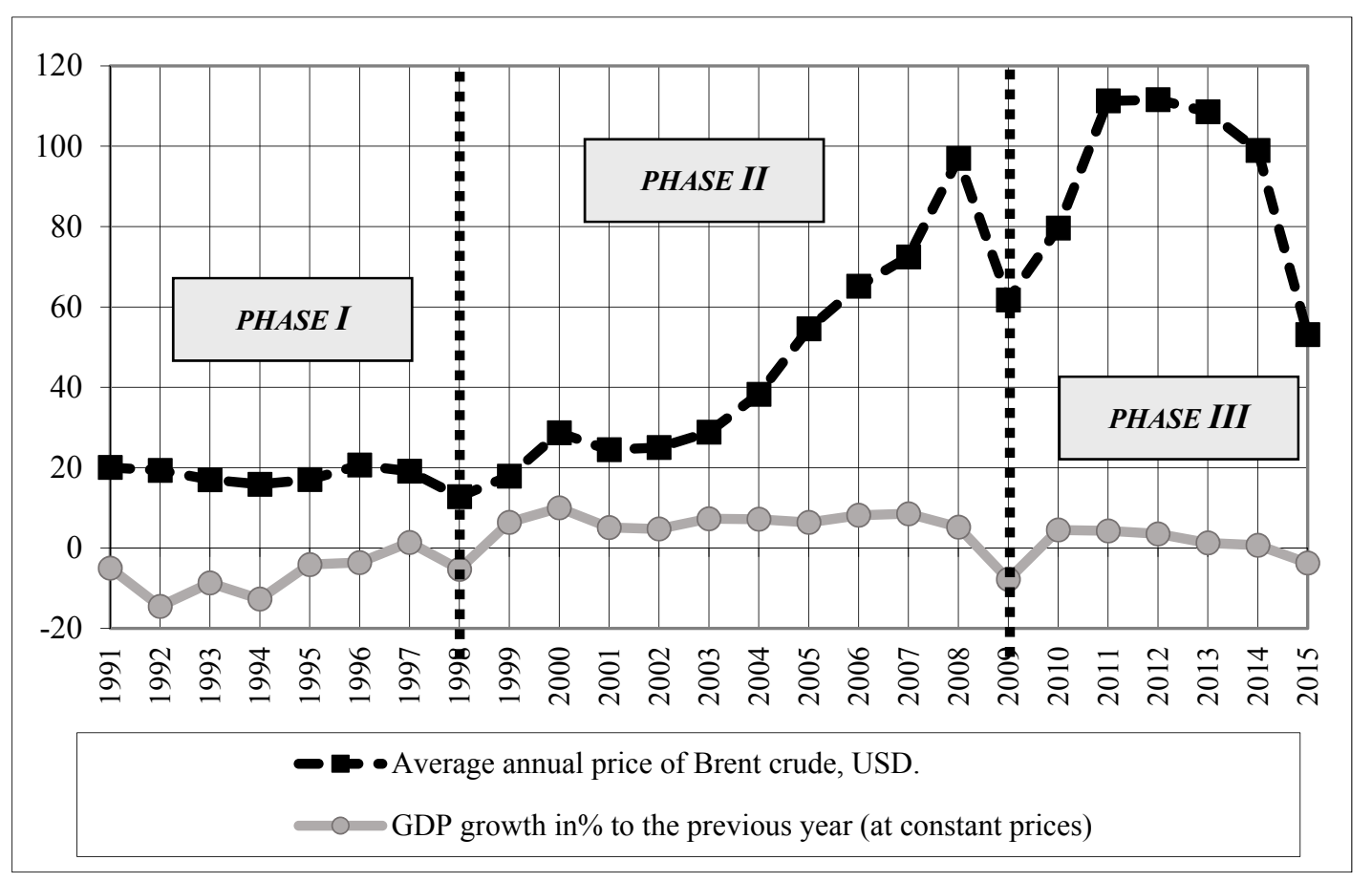

Figure 2. The relation between annual average Brent crude oil prices (Note 3) (US\$ per barrel) and the Russian Federation GDP growth rate (Note 4 ) (\% to the previous year, in constant prices) (calculated by the author)

\section{Results}

Each phase indicated has the following characteristics:

Phase I: 1991-1998 (the initial period of the market transition with rather stable low Brent crude oil prices, about US $\$ 20$ a barrel, a sustainable decline of GDP and investment activity, the average annual price fell less than US\$13 a barrel in 1998, the economic crises resulted in the real GDP decline and the devaluation of national currency, Fig. 2);

Phase II: 1999-2008 (thanks to the favourable state of the global energy market, oil price increase, and devaluation, we could see the GDP and investment recovery but a new drop in global energy prices at the end of 2008 caused another GDP decline and rouble devaluation);

Phase III: 2009-2015 (the short GDP and investment growth occurred in a correlation with energy carrier prices but due to geopolitical constraints, the introduction of anti-Russian sanctions, and the fall of global crude oil prices at the end of 2014 the problem of the Russian economic security seems to come first). 
A high correlation of GDP and crude oil prices during the whole period of marker reforms is fundamental and related to the fact that the official statistics about the share of oil sector in GDP are greatly underestimated. For example, to avoid taxes many companies sell their produce to trade (intermediate) companies being their subsidiaries at below market prices, the underestimated prices are considered to be transfer ones. Further intermediate companies sell mineral products recovered to end buyers through offshores. Therefore, the considerable part of a mining industry added value transfers to a service industry or remains in offshores abroad and so is not taken into account by the Federal State Statistics Service.

In 2006 O. Berezinskaya and V. Mironov calculated that 'if the GDP structure were not distorted by transfer pricing and export price understatement, the situation would be different... According to our calculations its [mining industry] share makes not 6-9\% of GDP (according to official data) but $14-15 \%$ in 1996-1998 and more than $20 \%$ in 1999-2003. With the pipeline transportation taken into consideration, it made about a quarter of GDP in 1999-2003.'

Sergey Shmatko, the Minister of Energy from 2008 to 2012, spoke in his report to the RF State Duma on December 8, 2010, 'On the whole, I would like to mention that for the current period the fuel and energy sector remains dominant in the GDP volume, its share is reaching $30 \% \ldots$.'

In 1994, more than 20 years ago, Leonid Abalkin describing the economic circumstances of that time wrote, 'The production cutback is leading to inevitable exclusion of domestic producers not only from the world market but the domestic one... The development of such trend can become irreversible so the production would not be restored due to the lack of appropriate markets even with strong and massive financial and other support. Thereby the recovery and revitalization of the Russian economy would be impossible and the country would lose the chance to return to the circle of highly developed nation.' (Abalkin, 1994)

Today we have come to the situation when the domestic producers are practically excluded from both the world and domestic market but it is difficult to assess if we came to the point when the process became irreversible.

Let us calculate the values of key investment indicators of the economic growth on the average over the economy transformation periods spoken above (Table 3).

Table 3 shows that in the first phase of market transformation in 1991-1998 the GDP physical volume calculated in constant prices fell by $42.5 \%$, the fall making about $6.7 \%$ a year on the average. In the second phase the crude oil price increase and rouble devaluation caused the GDP growth (by $79.5 \%$ over the whole period and by about $5.5 \%$ a year on the average) and investment revival. In the third phase of market transformations after the 2008 crisis the rate of the economic growth and investment activities has noticeably decelerated.

Table 3. The investment security of the Russian Federation's economy over the period of market transformation (Source: Calculated by the data of Federal State Statistics Service)

\begin{tabular}{lrrr}
\hline & $\begin{array}{r}\text { Phase I } \\
\text { 1991-1998 }\end{array}$ & $\begin{array}{r}\text { Phase II } \\
\mathbf{1 9 9 9 - 2 0 0 9}\end{array}$ & $\begin{array}{c}\text { Phase III } \\
\mathbf{2 0 1 0 - 2 0 1 5}\end{array}$ \\
\hline $\begin{array}{l}\text { GDP growth rate over the whole period (calculated in constant } \\
\text { prices), \% }\end{array}$ & $-42.50 \%$ & $79.50 \%$ & $15.00 \%$ \\
Annual average GDP growth rate in constant prices, \% & $-6.69 \%$ & $5.46 \%$ & $2.82 \%$ \\
Growth of fixed assets volume over the whole period, \% & $5.36 \%$ & $21.48 \%$ & $16.42 \%$ \\
Annual average growth rate of the fixed assets physical volume in & & & \\
comparable prices, \% & $0.65 \%$ & $1.79 \%$ & $3.87 \%$ \\
Investment growth over the whole period (in constant prices), $\%$ & $-78.89 \%$ & $184.71 \%$ & $4.55 \%$ \\
Annual average investment growth rate in constant prices, \% & $-17.67 \%$ & $9.98 \%$ & $4.08 \%$ \\
Annual average Brent crude oil price, US\$ & 17.72 & 46.73 & 93.85 \\
\hline
\end{tabular}

Further we are describing the transformation of the investment security of the economic growth in each phase.

It is worth noticing that in the first phase of market transformations (1990-1998) financial goals determined the priorities of the economic policy which pushed to the oblivion the development needs of the real sector of the economy. The concept of the Russian economy reforms in 1990s was based on monetary principles without regard for the existing peculiar institutional conditions which largely accounts for the failure in adopting imported market institutions. 
According to the book Institutional Constraints on Modern Economic Growth, 'The leaders of the first reformist government of Russia preferred to focus their efforts on some crucial areas of economic reforms in the narrowest sense: on price and trade liberalization, on privatization, on financial stabilization. ... in the first months and years of reforms they did not address the core of the old institutional system so with time they were hampered by the constraints connected with government failures in key areas of its responsibility: justice, security, and defense.' (Lisin, Yanovsky, et al, 2011).

The degree of readiness of various institutes to radical reforms in economic, political, and social spheres was not studied. The cultural consciousness of the Russians did not favour market reforms they actually hampered them.

The author relates the intrinsic causes of a deep transformational decrease in the market transition with the fact that the majority of new enterprise owners do not have long-term investment development plans so 'the firm activities are regulated by short-term needs and the new owners' motive of self-enrichment dominates the objectives of production development.'

This phenomenon of development when a personal interest does not correspond to the enterprise's interest or collective public interests, the desire of individual enrichment prevails over the development objectives was described by George Kleiner as 'economics of individuals' (Kleiner, 1996). It is a paradoxical situation in terms of the enterprise development promotion when deals are made to serve individual interests with prejudice to the interests of the enterprise. It is largely connected with the perceptions of insecurity and high economic and political risks when it is highly probable to lose business due to economic and political reasons and, therefore, the concern for individual ownership takes priority over the concern for an enterprise.

As a result the savings and current account deficits occur. The savings deficit becomes evident when the level of savings available for the industry is much lower than the volume of investments necessary for the production development. The low level of savings reflects the shrinking public confidence in the existing financial institutions. The household propensity to save in the period indicated is mainly realized in accumulating foreign currencies, real estate, and other non-liquid assets not accumulated by financial institutions. Under such conditions the source of accumulation is an external loan resulting in trade and payment deficit. Besides, the import of foreign loan capital into Russia is accompanied by heavy illegal capital export, not reported by official statistics.

The consequence of the changes was the increase of a crisis potential: economic recession, investment reduction, critical state of production facilities, negative shifts in the economy structure to the development of, mainly, a trade-intermediary sector, a further consolidation of the established development model based on raw material exports, the reinforcement of income differentiation between different sectors of economic activity and territories, deformation of money supply and payment system, expatriation of assets, budget deficit increase, and social problem accumulation (Igonina, 2013).

The capital outflow from a real sector to a financial one associated with the difference in the return on investment level has led to both the reduction in financial resources in a production environment and the overgrowth of a financial sector which was not based on a stable reproduction basis. The share of long-term credits in a total volume of bank assets made 3-4\%, with credit interest rates being 5-16 times higher than the industrial production profitability level. Accumulating up to $90 \%$ of population savings and enterprises' assets, banks invested them primarily in government securities which were the most attractive in terms of revenue, reliability, and liquidity. Moreover, more than $80 \%$ of the Russian capital market was capitalized by fuel and energy companies' shares.

In regard to capital export in the years of reform, namely the total amount of capital exported from Russia, the estimates of various expert centers vary in magnitudes. Differences stem mainly from the lack of reliable and complete information on the operations of the initial period of reforms (The Central Bank of Russia has been reporting on the balance of payments and withdrawal of capital from our country only since 1994, but not 1992).

'The most appropriate of the best available assessments is made by the Russian Finance Ministry. According to it, a net flight of capital from Russia amounted to US\$265-285 bn in 1986-1995. With due consideration of the capital outflow in the following years (US\$142.3 bn), the period of reforms in Russia plundered the country to the astronomical amount of US\$407.3-427.3 bn. According to experts of the Association of Russian banks, the amount of capital (i.e. taking into account public funds and not including foreign capital influx) transferred abroad in the 1990s was within the range of US $\$ 800$ bn-US\$1tn.' (Igonina, 2013).

The second phase of market transformations started in 1999-2000s when positive trends on the world's energy markets and the depreciatory effects contributed to the breaking-out of a lengthy and severe period of recession 
in the Russian economy. These factors led to the development of export-oriented manufacturing, influx of currency returns, gradual expansion of money supply and lower interest rates. However, a development model based on a concentrated proprietary, oligopolistic structure of business, export of raw materials was subjected to high market fluctuations depending on the world market prices and resulted in building-up internal risks and threats.

The main road block hampering the development of the Russian economy and being apparent in the second phase of market transformations, consists, in the opinion of V.K. Senchagov, in the fact that 'the financial and banking system, corporate management and all the parts of government machinery are not able to use for the benefit of the country and its citizens the accumulated resource potential and funds the country has earned in the favourable pricing environment. This was proved by the experience of 2000-2004 when our financial and banking system was unable to convert auxiliary income into investments (Senchagov, 2001).'

Due to existing structural and functional characteristics, 'the Russian economic system is very sensitive to such external shocks as a global economic slowdown, worsening of price environment in oil markets, a drop of liquidity in global financial markets' (Igonina, 2013). As a result, the effects of the 2008 global crisis proved to be more significant for the Russian economy than for other countries. All that greatly complicated the tasks of restoring and building the economy.

A key feature of the third phase of the market transformations which began after the 2008 crisis was a sharp increase in capital outflows. According to the Central Bank of the RF's official data, it amounted to US $\$ 133.6$ bn in 2008, US\$153 bn - in 2014 and for the period of five years (2010-2014, not taking into account the data of 2015 ) it was more than US\$380 bn (Note 5).

According to Karl Marx, capital export and flows are possible due to the fact that countries with different levels of economic development are involved in a global capital turnover. In developing countries the profit is high as the organic composition of capital is low, labor and raw materials are cheap, and land is low-cost. 'If capital is exported abroad, it is not because it could not find an application in the country. The reason is that capital can be placed at a higher rate of return abroad (Marx, 1961, V.25, p. 281).' The drive to maximize profits entails both the capital flow and its renovation. 'None of the capitalists switches over to a new method of production on their own accord, no matter however productive it is and increases the rate of surplus value, provided that it reduces the rate of profit (Ibid, p. 290).'

Karl Marx said that capital renovation is based on the desire of businessmen to increase a profit rate. This is exactly what creates motivation and interest in investment.

With regard to the Russian Federation there is a steady tendency to decrease the return rate on equity and sales throughout the whole period of market transformations.

Since the base of capital movement and its renewal, i.e. a motive for investing, by definition is a pursuit of higher profits, the activation of investment process seems to have quite a hard time realizing (Table 4).

Table 4. Dynamics of entities' profitability (excluding small businesses) in the Russian Federation (Source: Federal Service of State Statistics)

\begin{tabular}{ccc}
\hline & Return on total assets & Profitability of goods, produce, works and services sold \\
\hline 1995 & 5.3 & 15.8 \\
2000 & 7.6 & 18.9 \\
2005 & 8.8 & 13.5 \\
2010 & 6.7 & 10.0 \\
2011 & 6.5 & 9.6 \\
2012 & 6.1 & 8.6 \\
2013 & 4.5 & 7.0 \\
2014 & 2.5 & 7.3 \\
\hline
\end{tabular}

Thus, according to the Federal Service of State Statistics data the profitability of mining operations in 2014 was $22.2 \%$, the profitability of mining operations except fuel and energy $-36.0 \%$, the profitability of the electrical machinery, electronic and optical equipment production $-10.2 \%$, the profitability of machinery manufacturing $6.8 \%$, that of the transportation means and transport equipment production $-5.5 \%$ (Note 6). In these 
circumstances it proves challenging to ensure the further growth of investments into high-tech and knowledge-intensive industries so it seems to be impossible to speak about the economy development.

In the third phase of market reforms, the GDP recovery up to a pre-crisis level in Russia was achieved mainly on account of the fuel and energy industry and high energy prices in the world market (Figure 2 and Table 3 ). In fact, according to the Federal Service of State Statistics data the volume of investments into fixed assets increased only in 2010-2012, with physical quantity of investments decreasing from 2013 onwards. But the indicator of fixed investment has not reached the pre-crisis level despite the favourable situation on the world energy market. The analysis shows that the reproduction model of funds available for investment by means of raw materials cannot provide a necessary volume of investments into fixed assets and ensure a sufficient economic growth.

The situation was complicated by the significant capital outflow (in 2014 - US $\$ 153$ bn, in 2010-2014 - more than US $\$ 380$ bn), as already mentioned above, and accompanied by the fall in crude oil prices from the late 2014 onwards. All that led to the reduction in federal budget revenue and sequestering treasuries at all levels.

\section{Discussion}

An income level determines possibilities of the economic system at any level including the national economy. Samuel Bazzi and Christopher Blattman considered the national income size as a key factor of national development. The authors proved the relationship between national income and political stability. Revenue growth reduces the intensity of internal social and political threats, opposition movements and decreases private incentives to continue the existing social conflicts (Bazzi, Blattman, 2014).

The reasons for the crisis occurrence are divided into economic and institutional, threats and risks have the following subgroups which can play more or less important role (according to different analysts)..

Economic threats and risks are

- RESOURCES AND TECHNOLOGIES (Endress, 2015): deterioration of material and technical basis and technologies; disruption of industrial potential; high level of raw material dependency etc.

- MARKET (Sandri, 2014): market structure changing; sales markets loss; market position falloff; collapse of competitiveness and competitive advantages; monopolies' activities enhancing etc.

- FINANCE (Gourio, 2013), (Bussière, Imbs, Kollmann, Rancière, 2013): financial situation disturbance; inability to pay; financial liquidity decrease; high level of financial dependency; financial sustainability deterioration etc.

Institutional threats and risks are

- SOCIAL (Imrohoroğlu, Kitao, 2012), (Coile, Levine, 2011), (Dynan, 2009), (Clark, 2004) (Artigea, Dedrya and Pestieaub, 2014) (Chen, Fang,. 2013): social situation decadency; migration; labor motivation decrease; living standards deterioration; high rate of social conflicts etc.

- LEGISLATIVE (Arnolda, Hübnerb, 2010): economic criminality; economic crimes growth; low level of legal safety; legislative framework changes.

- ADMINISTRATIVE AND POLITICAL (Chomaa, Hanocha, Gummeruma, Hodsonb, 2013): changes in institutional conditions and guarantees of economic activity; political situation degradation; change of leadership and economic policy principles etc.

In regard to economic development, the relationship between social and financial factors is evident (Azzimonti, Francisco, and Quadrini. 2014). Under conditions of budget deficit, social security can become a source of serious social conflicts which can pose a threat to the development and sustainability of a socio-economic system. According to a number of authors (Senchagov, 1995), etc., substantial disparities in population income and consumption, incidence of poverty, increasing number of people living below the poverty line constitute a dire threat to the economic development of the country.

In studies of foreign authors social factors play quite a significant role in the long-term sustainable development. In particular, Selahattin Imrohoroglu and Sagiri Kitao (2012) proposed a model where they correlate medical expenses, wages, and public health to potential threats of life support.

Professor Lee H. Endress, the former head of the Asian and Pacific Center for Security Studies, in his book Sustainable Economic Development. Resources, Environment and Institutions (Sect.3 Scarcity, Security, and Sustainable Development) published in 2015, related the securing of social and economic systems with their sustainable development in conditions of natural scarcity (Endress, 2015). The author examined the relationship between a deficit of natural resources, security and sustainable development. The fear of physical scarcity, 
according to the author, may lead to a desire to ensure security through measures that can undermine both the security itself and the economic well-being.

Comparing population income levels with those of debt-service obligations, Karen Dynan notes that 'over the past few decades financial capacities of households and population incomes have increased significantly (Dynan, 2009).' Advanced financial opportunities coupled with further credit availabilities contributed to more investments into risky assets amid the unforeseen income fluctuations, as a result obligations were at odds with resources. That is a sure sign of aggregate economic instability, destabilization of individual households and economy as a whole.

Social inequality and society polarization in Russia increased in the 1991-2015 economy reformation period. Table 5 shows the distribution of population incomes within the period according to official statistics.

The situation at hand is plotted in Figure 3. It shows that there has been a significant shift of the Lorenz curve to the right, towards inequality gain.

Table 5. Distribution of population income in Russia in 1991-2014, \% (Source: Federal Service of State Statistics)

\begin{tabular}{lcccccc}
\hline & $\mathbf{1 9 9 1}$ & $\mathbf{1 9 9 5}$ & $\mathbf{2 0 0 0}$ & $\mathbf{2 0 0 5}$ & $\mathbf{2 0 1 0}$ & $\mathbf{2 0 1 4}$ \\
\hline Distribution of total income by 20 \% population groups & 100 & 100 & 100 & 100 & 100 & 100 \\
first (the lowest income) & 11.9 & 6.1 & 5.9 & 5.4 & 5.2 & 5.2 \\
second & 15.8 & 10.8 & 10.4 & 10.1 & 9.8 & 9.9 \\
third & 18.8 & 15.2 & 15.1 & 15.1 & 14.8 & 14.9 \\
fourth & 22,8 & 21,6 & 21,9 & 22,7 & 22,5 & 22,6 \\
fifth (the highest income) & 30.7 & 46.3 & 46.7 & 46.7 & 47.7 & 47.4 \\
Gini index (income concentration index) & 0.26 & 0.387 & 0.395 & 0.409 & 0.421 & 0.416 \\
\hline
\end{tabular}

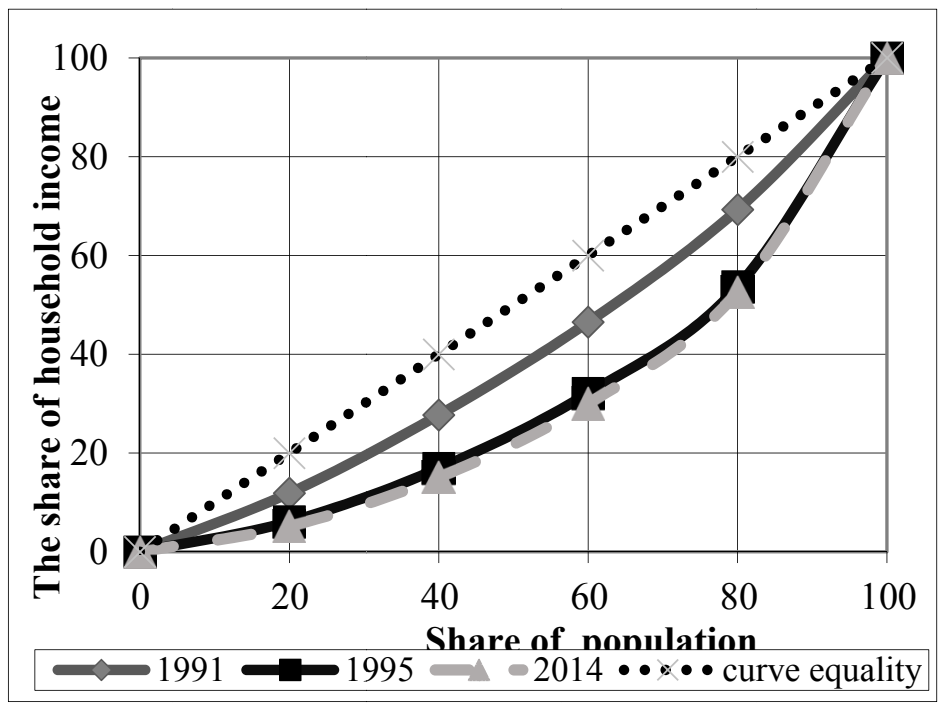

Figure 3. Shift of the Lorenz curve in Russia in1991-2015 (Source: constructed by the author)

It should be noted that the Federal State Statistics Service underreports the data on inequality level due to the existing data collection system which does not take into account the informal economy. At the same time high incomes tend to avoid paying taxes.

Nevertheless, even according to the Federal State Statistics Service there is a stable trend towards greater inequality. The gap between population incomes boosted in the first half of the 1990s. Huge difference in living conditions of population is perceived by the society as a violation of social equity principles and can lead to the escalation of efferent tendencies and separatism, the deterioration of economic security in some regions and in the Russian Federation as a whole.

As for the estimation of socio-economic development it is worth mentioning that there is an idea that 'the 
traditional macroeconomic development indicators like GDP do not meet modern challenges, and their use can lead to conservation and aggravation of existing social, environmental and economic negative trends (Bobylev, Sergey, Zubarevich, \& Solov'eva, 2015).' The authors propose to change the approach to the measurement of development indicators by putting emphasis on social and environmental performance.

Along with the drop in welfare and quality of life, the 1990s reforms impaired significantly the demographic situation. In the long run enhancing mortality and falling birth rates led to the negative values of natural population growth that was observed for the first time from the beginning of the XX century (Andreev, Darskii., \& Khar'kova, 1998). The dynamics of birth and death rates in Russia in 1950-2014 is plotted in Figure 4.

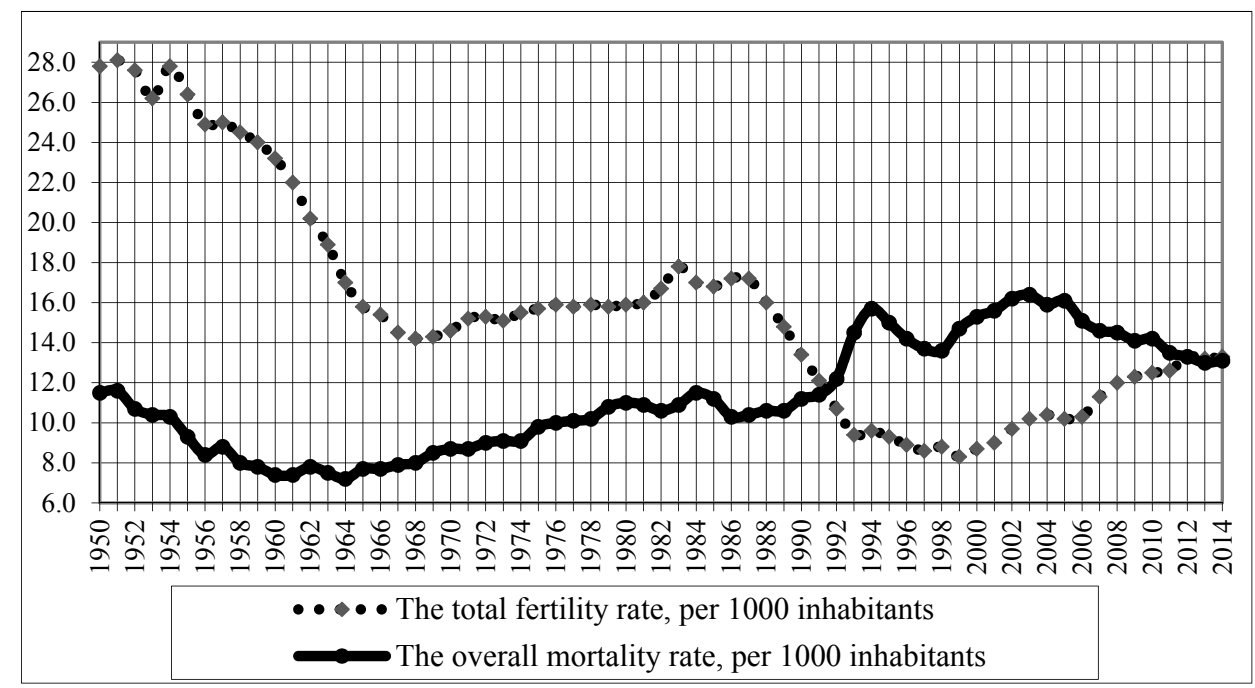

Figure 4. Dynamics of birth and death rates in Russia in 1950-2014 (Source: Federal Service of State Statistics)

Being a determinant of the population reproduction the joint dynamics of birth and death rates shows that despite the systematic decline the reproduction of the Russian population had expanded by the end of the 1950s (with the exception of mass starvation periods in 1933-1934, 1947-1948, and in the war period).

During the years of market reforms Russia experienced the rising incidence of major diseases associated with high levels of stress and poor quality of life and respectively the increase in mortality. During these periods a male mortality rate at young age was very high, several times as much that of women. Men were much more sensitive to disasters of the 90 s than women.

During the period of economic reforms the rate of certain diseases significantly increased in general. For example, if the total number of registered diseases in patients with the diagnosis determined for the first time increased by $16 \%$ in comparison with 1991, with the population being down by $3 \%$ in 2014 , the incidence of diseases of blood and blood-forming organs and certain disorders involving the immune mechanism became 3 times as many; endocrine diseases and metabolic disorders - 2.8 times; diseases of the circulatory system -2.6 times; congenital anomalies / birth defects, deformations and chromosomal abnormalities -2.5 times (Note 7).

In addition, incidence of malignant tumors increased by nearly $30 \%$, active tuberculosis - by $73 \%$ as compared with 1991. Notably, in the 1990s, at the first stage of reforms there was a sharp increase in the incidence of active tuberculosis, 2000 evidenced a 2.6 increase of the disease incidence, afterwards there was observed a slowdown.

The lack of a generated hazard management mechanism due to the problems inherent in the overall system and threatening national economy promoted an aggravation in a number of economy sectors, first of all, basic infrastructure industries: public health service, education, system of courts and law enforcement. This has a knock-on effect on the development and national security of regions and country as a whole, reduces the population living standards.

The population incidence rate may be associated both with health care quality and environmental degradation. The state of the environment can threaten the sustainable development of a country, a society, and a world civilization. Environmental degradation leads to the biosphere (life sphere) destabilization, the loss of its integrity, the inability to maintain desired vital qualities of environment. 
The results of the research do not seem to escape the conclusion that current investment crisis in Russia is quite logical. There have been no significant changes in economy despite an extensive discussion and long-term debates on the problem of obsolescence of a source-based economy model based on the accelerated export of fuel and raw materials and the low cost of such production factors as labor, fuel, and electricity.

Assessing the current economic state of our country Sergey Afontsev says that the absence of Russia's full-fledged access to international markets of goods, capital, and technology 'could mean the minimization of the crisis damage in a best case scenario but not the prospects of overcoming it (Afontsev, 2015).'

To implement import substitution in the long term domestic companies should be able to invest in the expansion of production, technological modernization, and performance efficiency. This requires an access to sources of capital and technologies on the basis of which new production capacities can be set up.

The high country risk, the current lack of potential investors' trust in state institutions, the non-availability of a viable protection mechanism for property rights and security of investments in order to prevent the possibility of state or competitors' expropriation, the lack of mechanisms of transforming savings into capital investments led to a current investment crisis in Russia.

\section{Acknowledgement}

Supported by the Russian Humanitarian Scientific Foundation grant № 16-02-00213.

\section{References}

Abalkin. L. (1994). The economic security of Russia. Threats and their reflection. Voprosy Ekonomiki, 12, 4-13. ISSN: 0042-8736. http://elibrary.ru/item.asp?id=21823790

Afontsev. S. (2015). Crisis Management under Economic Sanctions: Mission Impossible? Voprosy Ekonomiki, 4, 20-36. ISSN: 0042-8736. http://elibrary.ru/item.asp?id=23167197

Andreev, E., Darskii L., \& Khar'kova T. (1998). Demographic History of Russia: 1927-1959. Population and Society, 31. http://www.demoscope.ru/acrobat/ps31.pdf

Arnolda, V., Hübnerb, M. (2010, December). Income redistribution and criminality in a growing economy // International Review of Law and Economics, 30(4), 338-344. http://dx.doi.org/10.1016/j.irle.2010.08.002

Artigea, L., Dedrya, A., Pestieaub, P. (2014). Social security and economic integration. Economics Letters. 123(3) 318-322. http://dx.doi.org/10.1016/j.econlet.2014.02.027

Azzimonti, M., Francisco, E., \& Quadrini, V. (2014). Financial Globalization, Inequality, and the Rising Public Debt. American Economic Review, 104(8), 2267-2302. http://dx.doi.org/10.1257/aer.104.8.2267

Bazzi, S., Blattman, C. (2014, October). Economic Shocks and Conflict: Evidence from Commodity Prices. American Economic Journal: Macroeconomics, 6(4), 1-38. http://dx.doi.org/10.1257/mac.6.4.1

Bobylev, S., Zubarevich, N., Solovyeva, S. (2015). Challenges of the Crisis: How to Measure Sustainable Development? Voprosy Ekonomiki, 1, 147-160. ISSN: 0042-8736. http://elibrary.ru/item.asp?id=22917353

Bussière, M., Imbs, J., Kollmann, R., Rancière R., (2013, July). The Financial Crisis: Lessons for International Macroeconomics. American Economic Journal: Macroeconomics, 5(3), 75-84. http://dx.doi.org/10.1257/mac.5.3.75

Chen, H.-J., Fang, I-H. (2013, May). Migration, social security, and economic growth. Economic Modelling. 32, 386-399. http://dx.doi.org/10.1016/J.ECONMOD.2013.02.026

Chomaa B., Hanocha Y., Gummeruma M., Hodsonb G. (2013, January). Relations between risk perceptions and socio-political ideology are domain- and ideology- dependent. Personality and Individual Differences. 54(1), 29-34. http://dx.doi.org/10.1016/j.paid.2012.07.028

Clark, R. L, (2004, May). Social Security Financing: Facts, Fantasies, Foibles, and Follies. American Economic Review, 94(2), 182-186. http://dx.doi.org/10.1257/0002828041301678 .

Coile, C. C., Levine, P. B. (2011, May). Recessions, Retirement, and Social Security. American Economic Review, 101(3), 23-28. http://dx.doi.org/10.1257/aer.101.3.23 .

Dynan, K. E. (2009). Changing Household Financial Opportunities and Economic Security. Journal of Economic Perspectives, 23(4), 49-68. http://dx.doi.org/10.1257/jep.23.4.49 .

Endress, L. H. (2015). Sustainable Economic Development. Resources, Environment and Institutions. Chap. 3: Scarcity

Security,

$\&$

Sustainable

Development.

49-66. 
http://dx.doi.org/10.1016/B978-0-12-800347-3.00003-0

Gourio, F. (2013, July). Credit Risk and Disaster Risk. American Economic Journal: Macroeconomics, 5(3), 1-34. http://dx.doi.org/10.1257/mac.5.3.1

Igonina, L. (2013, January). Economic security of Russia in the system of macroeconomic investment criteria, National Interests: priorities and security, 2(191), 49-57. ISSN: 2073-2872. eISSN: 2311-875X http://elibrary.ru/item.asp?id=18395664

Imrohoroğlu, S., \& Kitao, S, (2012, July). Social Security Reforms: Benefit Claiming, Labor Force Participation, and Long-Run Sustainability. American Economic Journal: Macroeconomics, 4(3), 96-127. http://dx.doi.org/10.1257/mac.4.3.96 .

Kleiner, G. (1996) Russia's Economy of Today as "the Economy of Physical Entities". Voprosy Ekonomiki, 4, 81-95. ISSN: 0042-8736. http://elibrary.ru/item.asp?id=25395808

Lisin, V., Yanovsky, K. et al (2011). Institutional constraints of modern economic growth. Moscow: «Delo», RANEPA, p. 40. ISBN: 978-5-7749-0668-0. http://elibrary.ru/item.asp?id=19967911

Marx, K., \& Engels, F. (1960). Works. 2nd ed. V. 23. Moscow: State Publishing House of Political Literature. p. 642. http://publ.lib.ru/ARCHIVES/M/MARKS_Karl,_ENGEL'S_Fridrih/_Marks_K.,_Engel's_F..html\#043

Marx, K., \& Engels, F. (1961). Works (2nd ed.). V. 25. Moscow: State Publishing House of Political Literature. http://publ.lib.ru/ARCHIVES/M/MARKS_Karl,_ENGEL'S_Fridrih/_Marks_K.,_Engel's_F..html\#043

Naryshkin, S. (2010). Investment Security as a Factor of Steady Economic Development. Voprosy Ekonomiki, 5, 16-25. ISSN: 0042-8736. http://elibrary.ru/item.asp?id=13922701

Sandri, D. (2014, July). Growth and Capital Flows with Risky Entrepreneurship. American Economic Journal: Macroeconomics, 6(3), 102-23. http://dx.doi.org/10.1257/mac.6.3.102

Senchagov, V. (1995). The essence and basis of the strategy of economic security of Russia. Voprosy Ekonomiki, 1, 97-106. ISSN: 0042-8736.

Senchagov, V. (2001). Economic Security as a Basis of Russia's National Security. Voprosy Ekonomiki, 8, 64-79. ISSN: 0042-8736. http://elibrary.ru/item.asp?id=14955697

\section{Notes}

Note 1. International Monetary Fund (IMF). http://data.imf.org/?sk=29e74e46-0824-427f-bbde-af108686157f \&sId=1390030109571 (accessed May 10, 2016)

Note 2. As of http://www.gks.ru/wps/wcm/connect/rosstat_main/rosstat/ru/statistics/ftrade/ (accessed October 8, 2015)

Note 3. Calculated by the author according to https://www.quandl.com/data/DOE/RBRTE-Europe-Brent-CrudeOil-Spot-Price-FOB (accessed May 10, 2016)

Note 4. Calculated by the author according to Federal State Statistics Service. http://www.gks.ru/wps/wcm/ connect/rosstat_main/rosstat/ru/statistics/publications/catalog/doc_1270707126016 (accessed May 10, 2016)

Note 5. The Central Bank of the Russian Federation: Statistics of External Sector. Net Export (Import) of Capital from the RF by Private Sector according to Balance of Payments http://www.cbr.ru/statistics/?PrtId=svs (accessed May 10, 2016)

Note 6. Russia by Numbers, 2015: Brief Statistical Yearbook, Rosstat, M. 2015, pp. 417-418

Note 7. Calculated by the author according to Federal State Statistics Service. http://www.gks.ru/wps/wcm/ connect/rosstat_main/rosstat/ru/statistics/publications/catalog/doc_1270707126016 (accessed May 10, 2016)

\section{Copyrights}

Copyright for this article is retained by the author(s), with first publication rights granted to the journal.

This is an open-access article distributed under the terms and conditions of the Creative Commons Attribution license (http://creativecommons.org/licenses/by/4.0/). 